LAMBOT et al. (1979) found comparable results : the optimum crude protein concentration for growth and nitrogen utilisation is about $13.3-12.2$ and 11.4 per cent at body weights of 250,350 and $450 \mathrm{~kg}$. The effect of the ration protein content is presented in Table 3 .

\title{
References
}

Boucque Ch. V., Cotryn B.G., Buysse F.X. 1976, Maize silage with or without NPN, dehydrated whole-crop maize pellets or high moisture maize grain for finishing bulls. Anim. Feed Sci. Technol., 1, 347.

Boudque Ch. V., Cottyn B.G., Aerts J.V., Buysse F.X., 1976. Dried sugar beet pulp as a high energy feed for beef cattle. Anim. Feed Sci. Technol., 1, 643.

Boucque Ch. V., CotTyn B.G., BuYsse F.X., 1978. Bull fattening with dehydrated wholecorn-plant pellets compared with corn silage and high-moisture grain. Proc. 2nd International Green Crop Drying Congress, August, 1978 p. 327.

Boucque Ch. V., Fiems L.O., CotTyn B.G., Buysse F.X., 1978. Utilization of some industrial by-products in beef production. European Congress for Improved Beef Productivity, Paris, 28-29 September 1978.

Boucque Ch. V., 1979 . Unpublished data.

Buysse F.X., Boucque Ch. V., Eechout W., 1966. Intensive beef production (baby-beef) principally on concentrates. Communication of the Institute No. 125.

Buysse F.X., Eeckhout W., 1970. Besoins en protéines de jeunes taureaux soumis à un régime d'engraissement intensif. Rev. Agric. Brux., 23, 703.

Cottyn B.G., Bouceue Ch. V., Buysse F.X., 1970. La valeur des betteraves fourragères pour la production intensive de viande bovine. Rev. Agric., Brux., 23, 501.

CotTyn B.G., Bouceue Ch. V., Buysse F.X., 1976. Complete dry rations based on dried sugar beet pulp and rolled barley for intensive beef production. Z. Tierphysiol., Tierernährg. u. Futtermittelkde. 37, 99.

CVB., 1979. Voedernormen voor de landbouwhuisdieren en voederwaarde van veevoeders. Verkorte tabel. Centraal Veevoederbureau in Nederland.

Eeckнout W., BuYsSE F.X., 1972. Recherches complémentaires concernant les besoins en protéines de taurillons (baby-beef) engraissés de manière intensive. Rev. Agric. Brux., 25, 21.

I ambot O., Bienfait J.M., Van Eenaeme C., Nicks B., Cordiez E., 1979. Etude de trois niveaux protéiques dans des régimes à base de maïs déshydraté pour des jeunes bovins en croissance - engraissement. Ann. Méd. Vét., 123, 195.

MERTENS D.R., 1977. Importance and measurement of protein insolubility in ruminant diets. Proc. Georgia Nutrition Conference, p. 30.

\section{Danish energy and protein feeding standards for growing and fattening cattle}

\section{H. REFSGAARD ANDERSEN and J. FOLDAGER}

The National Institute of Animal Science

Rolighedsvej 25, DK 1958 Copenhagen V, Denmark

\section{Introduction}

In Denmark the energy value of feeds as well as the energy requirements of growing animals and milking cows are still expressed as Scandinavian Feed Units (SFU). One SFU is equivalent to the energy content of $1 \mathrm{~kg}$ barley ( 85 per cent dry matter). The advantages of this system are the additivity of energy values of feeds, the simplicity of estimating ration composition for a given production, and the expected production from a defined ration.

The requirements for protein are expressed as digestible crude protein (DCP). 
TABLE 1

DANISH ENERGY ALLOWANCES FOR MEDIUM MATURING BULLS AND REPLACEMENT HEIFERS; SFU/DAY

\begin{tabular}{|c|c|c|c|c|c|c|c|}
\hline \multirow{2}{*}{$\begin{array}{c}\text { Liveweight } \\
\mathrm{kg}\end{array}$} & \multirow[b]{2}{*}{ Sex } & \multicolumn{6}{|c|}{ Dailyy_gain, } \\
\hline & & 400 & 600 & 800 & 1000 & 1200 & 1400 \\
\hline \multirow[t]{2}{*}{150} & $\sigma^{\pi}$ & - & 1.9 & 2.4 & 3.0 & 3.6 & - \\
\hline & $q$ & 1.2 & 2.0 & 2.9 & 3.9 & - & - \\
\hline \multirow[t]{2}{*}{200} & $\sigma$ & - & 2.4 & 2.9 & 3.5 & 4.1 & 4.9 \\
\hline & $\stackrel{0}{+}$ & 1.6 & 2.5 & 3.6 & 4.7 & - & $\cdot-$ \\
\hline \multirow[t]{2}{*}{250} & $\sigma^{\prime \prime}$ & - & 2.8 & 3.3 & 4.0 & 4.7 & 5.7 \\
\hline & $\stackrel{\circ}{+}$ & 2.0 & 3.1 & 4.3 & 5.6 & - & - \\
\hline \multirow[t]{2}{*}{300} & $\sigma$ & - & 3.2 & 3.8 & 4.5 & 5.4 & 7.0 \\
\hline & q & 2.3 & 3.5 & 4.9 & 6.7 & - & - \\
\hline \multirow[t]{2}{*}{350} & $\sigma^{7}$ & - & 3.6 & 4.3 & 5.1 & 6.4 & - \\
\hline & $\stackrel{0}{+}$ & 2.6 & 3.9 & 5.6 & 8.1 & - & - \\
\hline \multirow[t]{2}{*}{400} & $\sigma^{7}$ & - & 4.0 & 4.8 & 5.8 & 8.0 & - \\
\hline & $\stackrel{0}{+}$ & 2.7 & 4.2 & 6.2 & - & - & - \\
\hline \multirow[t]{2}{*}{450} & $\sigma^{\prime}$ & - & 4.5 & 5.3 & 6.7 & - & - \\
\hline & $q$ & - & - & - & - & - & - \\
\hline \multirow[t]{2}{*}{500} & $\sigma^{1}$ & - & 4.9 & 5.9 & 8.2 & - & - \\
\hline & $\stackrel{0}{+}$ & - & - & - & - & - & - \\
\hline
\end{tabular}

Bulls: $A D G=206.5-4.27 \mathrm{~W}+0.002 \mathrm{~W}^{2}+574.7 \mathrm{E}-36.9 \mathrm{E}^{2}+0.038(\mathrm{WXE})$

Heifers: $A D G=550.8-3.83 W+0.006 W^{2}+312.5 E-10.3 E^{2}-0.27$ (WXE)

where $A D G=$ daily gain, $g ; W=$ liveweight, $k g ; E=S F U$ per day

\section{Energy value of feeds}

The content of SFU per $\mathrm{kg}$ feed dry matter is calculated as:

$\mathrm{SFU}=\left(1.43 . \mathrm{X}_{1}+k . \mathrm{X}_{2}+1.00 . \mathrm{X}_{3}+1.00 . \mathrm{X}_{4}\right) \times\left(\frac{\mathrm{V}}{0.75}\right)$

where SFU $=$ Scandinavian feed units per $\mathrm{kg}$ dry matter

$X_{1}=$ digestible crude protein, per cent of dry matter

$\mathrm{X}_{2}=$ digestible crude fat, per cent of dry matter

$X_{3}=$ digestible crude fibre, per cent of dry matter 
TABLE 2

EXPERIMENTS USED TO CALCULATE THE ENERGY ALLOWANCES FOR BULLS AND STEERS

\begin{tabular}{lclccc}
\hline Exp. no. & $\begin{array}{c}\text { No. of } \\
\text { animals }\end{array}$ & Breed & Sex & $\begin{array}{c}\text { Weight at } \\
\text { slaughter }\end{array}$ & $\begin{array}{c}\text { Relative } \\
\text { feeding level }\end{array}$ \\
Ka 416 & 168 & RDM & $\sigma^{7}$ & $180-540$ & $100-55$ \\
Ka 41 & 120 & SDM & $0^{\lambda}+0^{*}$ & $425-800$ & $100-70$ \\
Ka 49 & 420 & Crosses & $0^{*}$ & $320-560$ & $100-70$ \\
\hline
\end{tabular}

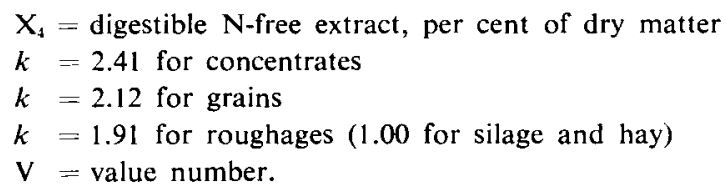

In most cases the coefficients of digestion are determined in experiments with mature sheep fed $1 \mathrm{~kg} \mathrm{DM} / \mathrm{day}$. The value number is determined in feeding trials with dairy cows. The digestibility coefficients and the value number of silage and hay may be calculated by regressions from the content of crude protein, crude fibre and ash.

Compared to other systems, e.g. fattening feed unit and starch equivalent, the SFU system overestimates the energy value of protein rich feeds because of a higher protein factor (1.43 vs 0.94). The nutritive value of various feeds is published in a booklet (ANDERSEN and JUST, 1975) which is revised approximately every five years.

Energy allowances for both bulls and replacement heifers (Table 1) have been determined from the relationship between daily gain and daily intake of SFU in feeding trials. The advantage of this procedure is, for example, that the allowance takes into consideration those differences in energy requirements for maintenance and gain which may exist due to differences in the level of feeding.

Energy requirements in bulls and steers, as well as the effects on carcase and meat quality, are under investigation in three experiments (Table 2). All experiments are initiated with calves at 73 days of age.

TABLE 3

EXPERIMENTS USED TO CALCULATE THE ENERGY ALLOWANCES FOR HEIFERS

\begin{tabular}{|c|c|c|c|c|c|}
\hline \multirow[t]{2}{*}{ Exp. no. } & \multirow[t]{2}{*}{$\begin{array}{l}\text { No. of } \\
\text { animals }\end{array}$} & \multirow[t]{2}{*}{ Breed } & \multicolumn{2}{|c|}{$\begin{array}{l}\text { Gain per group } \\
\text { at_300 kg; g/day }\end{array}$} & \multirow[t]{2}{*}{ Feeding method } \\
\hline & & & $\min$. & $\max$ & \\
\hline $\mathrm{Ka} 76$ & 34 & RDM & 597 & 658 & Restricted \\
\hline $\mathrm{Ka} 98$ & 69 & RDM & 685 & 918 & Restricted \\
\hline U 5 & 48 & SDM & 773 & 1032 & Ad $2 i b i$ tum $^{\mathrm{a}}$ \\
\hline U 6 & 96 & RDM & 354 & 926 & Ad $2 i b i$ tum $^{\mathrm{b}}$ \\
\hline
\end{tabular}

a silage/concentrate

b Barley straw/fodder sugar beets/concentrate 
TABLE 4

DANISH ALLOWANCES OF DIGESTIBLE CRUDE PROTEIN FOR MEDIUM MATURING YOUNG BULLS AND REPLACEMENT HEIFERS

\begin{tabular}{|c|c|c|}
\hline \multirow{2}{*}{$\begin{array}{l}\text { Weight } \\
\text { interval, } \\
\text { kg }\end{array}$} & \multicolumn{2}{|c|}{ Digestible_crude_protein, g/SFU } \\
\hline & Bulls ${ }^{a}$ & Replacement heifers \\
\hline-100 & 155 & 155 \\
\hline $100-150$ & 135 & 140 \\
\hline $150-200$ & 115 & 125 \\
\hline $200-250$ & 100 & 110 \\
\hline $250-300$ & 90 & 95 \\
\hline $300-350$ & 85 & 85 \\
\hline $350-400$ & 80 & 75 \\
\hline $400-450$ & 75 & 75 \\
\hline $450-500$ & 75 & 75 \\
\hline
\end{tabular}

The level of feeding is controlled by restricted feeding ; the energy concentration of the total ration (SFU/ $\mathrm{kg}$ DM) and DCP/SFU are kept constant. Only the first experiment (Ka 416) has been completed (ANDERSEN, 1975) and the energy allowances in Table 1 are based on that experiment. However, expected daily gains calculated by the regression for bulls in Table 1 are in agreement with daily gains obtained in feeding experiments with bulls fed various roughages : concentrate rations ad libitum and average results for more than 1000 RDM and SDM bulls on performance test stations. The energy allowance will be revised when all the experiments in Table 1 are completed.

The daily energy allowances for replacement heifers (Table 1) (Foldager et al., 1978) are calculated from feeding experiments where the main purpose was to estimate the optimum rearing intensity (Table 3 ).

In these trials the SFU/day were varied either by restricted feeding or free access to rations with various roughage : concentrate ratios. There was good agreement between daily gains for groups on restricted f'eeding and those fed ad libitum.

\section{Protein allowances}

The protein recommendations for young bulls and replacement heifers are shown in Table 4.

The recommendation for bulls (SøRENSEN and KousgaARD, 1976) was determined in feeding trials and included more than 400 animals. The feeding method was semi-ad libitum and the feeds were mainly grains and fodder sugar beets. The variable protein source was mainly soyabean meal but larger bulls were also fed mixtures of vegetable protein sources (soyabean meal, cotton seed cake, sunflower cake). The overall daily gains were $1000-1200 \mathrm{~g}$. It has not been clarified whether the recommendations in Table 4 are adequate when the energy intake is restricted and/or young bulls are fed rations containing more roughage than used in the experiments.

The recommendation for replacement heifers is based on experiments conducted in the forties (STEENSBERG, 1947 ; JENSEN et al., 1949). In these trials there was a total of 124 heifers. The experimental period was from birth to calving, and the daily allowance of SFU was in accordance with a standard for moderate feeding (the overall average daily gain was $400-500 \mathrm{~g}$ ). The heifers were at pasture during the summer periods. The allowance used is according to age but it has since been converted to recommendations for weight intervals. 


\section{References}

ANDERSEN P.E., Just A., 1975. Tabeller over fodermidlers sammensaetning m.m. 6 udg. Det. $k g l$. danske Landhusholdningsselskab, Copenhagen, $40 \mathrm{pp}$.

ANDERSEN H.R., 1975. The influence of slaughter weights and feeding level on the growth, feed conversion, carcass composition and conformation of bulls. 430 beretning fra Statens Husdyrbrugsfors $\varnothing \mathrm{g}$, Copenhagen, $124 \mathrm{pp}$.

FOLDAGER J., SEJRSEN Kr., LARSEN J.B., 1978. Opdraetningsintensitetens indflydelse pa yverets udvikling og maelkeproduktionen $i$ forste laktation. 226. meddelelse fra Statens Husdyrbrugsfors $\phi$ g.

JENSEN K., Steensberg V., Winther J.E., 1949. Proteinmaengdens inflydelse pa ungkvaegets vaekst. II. 237. beretning fra Forsogslaboratoriet. Statens Husdyrbrugsudvalg, Copenhagen, 103 pp.

STEENSBERg V., 1947. Proteinmaengdens indflydelse pa ungkvaegets vaekst. 227. beretning fra Fors $\varnothing$ gslaboratoriet. Statens Husdyrbrugsudvalg, Copenhagen, 103 pp.

Sørensen M., Kousgaard K., 1976. Effect of protein level on liveweight gain and quality of carcasses and meat quality in fattening calves and young bulls. 437. beretning fra Statens Husdyrbrugsfors $\emptyset \mathrm{g}$, Copenhagen, $26 \mathrm{pp}$.

\section{Finnish energy and protein feeding standards for growing and fattening cattle}

\section{TUORI}

Department of Animal Husbandry, University of Helsinki, Finland.

The official Finnish recommendations date from 1962 but they are no longer in use. The recommendations given here, although they are unofficial (MELEN, 1976), are widely followed. They are used in those feeding tables which are calculated for almost every herd belonging to the milk control system.

TABLE 1

ENERGY (FFU/day) AND PROTEIN RECOMMENDATIONS FOR GROWING BULLS

\begin{tabular}{|c|c|c|c|c|c|c|c|}
\hline \multirow{2}{*}{$\begin{array}{c}\text { Liveweight } \\
\mathrm{kg}\end{array}$} & \multicolumn{6}{|c|}{ Liveweight gain, g/day } & \multirow{2}{*}{$\begin{array}{c}9 \text { DCP/ } \\
\text { day }\end{array}$} \\
\hline & 700 & 800 & 900 & 1000 & 1. 100 & 1. 200 & \\
\hline $100-150$ & 2.8 & 2.9 & 3.0 & 3.2 & 3.4 & 3.7 & 138 \\
\hline $150-200$ & 3.1 & 3.3 & 3.5 & 3.8 & 4.1 & 4.5 & 128 \\
\hline $200-250$ & 3.4 & 3.7 & 4.0 & 4.4 & 4.8 & 5.3 & 119 \\
\hline $250-300$ & 3.8 & 4.2 & 4.5 & 5.0 & 5.5 & 6.1 & 113 \\
\hline $300-350$ & 4.2 & 4.7 & 5.1 & 5.7 & 6.3 & 7.0 & 108 \\
\hline $350-400$ & 4.7 & 5.2 & 5.7 & 6.4 & 7.1 & 7.9 & 105 \\
\hline $400-450$ & 5.2 & 5.8 & 6.4 & 7.1 & 7.9 & 8.8 & 102 \\
\hline $450-500$ & 5.8 & 6.4 & 7.1 & 7.9 & 8.8 & & 100 \\
\hline
\end{tabular}

